University for Business and Technology in Kosovo

UBT Knowledge Center

Oct 29th, 5:00 PM - 5:15 PM

\title{
Syrian Refugee Crisis and European Migration Policies: Rise in Xenophobic Rhetoric in Europe
}

Meltem Çelik Dirsehan

Marmara University, meltem.dirsehan@marmara.edu.tr

Follow this and additional works at: https://knowledgecenter.ubt-uni.net/conference

Part of the International Relations Commons

\section{Recommended Citation}

Dirsehan, Meltem Çelik, "Syrian Refugee Crisis and European Migration Policies: Rise in Xenophobic Rhetoric in Europe" (2017). UBT International Conference. 314.

https://knowledgecenter.ubt-uni.net/conference/2017/all-events/314

This Event is brought to you for free and open access by the Publication and Journals at UBT Knowledge Center. It has been accepted for inclusion in UBT International Conference by an authorized administrator of UBT Knowledge Center. For more information, please contact knowledge.center@ubt-uni.net. 


\title{
Syrian Refugee Crisis and European Migration Policies: Rise in Xenophobic Rhetoric in Europe
}

\author{
Meltem Çelik Dirsehan ${ }^{1}$ \\ Marmara University, Faculty of Science and Letters, Department of Sociology, \\ Göztepe Campus, Istanbul, Turkey, \\ meltem.dirsehan@marmara.edu.tr
}

\begin{abstract}
Syrian immigration crisis has been ignored by advanced European countries and the heaviest burden is left to developing border countries. However this ignorance has resulted in more mass influx of immigrants illegally to the borders of European Union with a target of advanced Northern countries. To evaluate the European ignorance to this humanitarian crisis, first Turkey is evaluated as a transition point for all Asian and Middle Eastern immigrants dreaming to live in Europe. By a shocking extend of sea arrivals, Europe have noticed the humanitarian crisis and made a deal with main transition point for immigrants, Turkey. However this deal is a symbol of violation human rights and vaporisation of all European values. So refugee crisis and policy changes in Europe are covered briefly. In conclusion, this position of European countries is argued as related with accelerating social support to xenophobic and Islamophobic rhetoric in politics as to elective results in advanced EU countries.
\end{abstract}

Keywords: refugee crisis, anti-immigrant policies, human rights, xenophobia in Europe

\section{Introduction: Syrian Refugee Crisis}

The main devastating effects of the Arab Spring eventuated in Syria and conflicts have deeply affected more than half of the Syrian population. This paper cites that the Arab Spring has a deep effect on changes in European policies; especially Syrian refugee crisis is corner stone to take the refugee crisis seriously. The main argument of this study is that the refugee flows and constructed fear of foreigners (especially fear for the rest of the west) have been abused by Xenophobic rhetoric in political milieu and media. After the first quarter of 2015, Turkey is the on the spot for European migration crisis because of that Turkey has been a transit point for Syrian immigrants who seeks high life standards shown by satellite/internet to undeveloped societies. For six years by then Syrian Civil War, the most traumatic refugee influx in the "age of migration" has created a huge mass mobility and humanitarian crisis. Regime forces, ISIS, YPG/PYD and other petit terrorist groups and poverty have expelled more than 7 million Syrians out of the country and various sectors of life, urban system and infrastructure (27\% housing stocks, public service buildings, roads, electricity systems, etc.) have been destroyed[1]. The first welcoming countries of Syrian population flow were border countries, Turkey, Lebanon, Jordan, and Iraq which hosted more than $84 \%$ of Syrian refugees while they are all developing countries and have already many socio-economic problems such as poverty and unemployment. However especially advanced Western countries have just only accepted nearly one million Syrian refugees and began to seek new solutions to keep refugees in 
conflict locations or border countries. Western welfare countries in European Union and other international associations have no effective initiative in solution for this humanitarian crisis, no decisive position for instance supporting Non-Fly Zone to keep security of Syrians in Syrian border, or diplomatic pressure to regime to stop the violence. Chaos in Syria has turned in a proxy war so many immigrants from Syria have built new lives in countries they have escaped, or they tried to get more than sustainable lives. Many Syrians, who live in secure locations with their relatives, targeted to live in Europe and they have joined in the immigration flow; crossed borders to reach European territory and apply for asylum. Until the sharp increase in sea arrivals (Table 1) has threatened European interests in 2015. Then, European Union have taken Syrian refugee crisis seriously and made a deal with Turkey in March 2016 not to accept more refugees by sea arrival.

\section{Turkey as transition point to Europe}

The most crowded Syrian refugee population live in Turkey, which has $21 \%$ of citizens under poverty threshold. Turkey has more than 3,4 million[2].Syrians and half a million asylum seekers coming from other countries which are in conflict or in economic insufficiency[3] Totally 4 million asylum seekers in Turkey have been waiting for a better life for their future and many of them dream on a life in Europe. Although allegedly Syrians in Turkey are escaping for survival, being a possible citizen in future in Turkey does not attract those lifestyle/opportunist immigrants in this case. Being an asylum seeker with a hope to be a European citizen at the end seems better than being a citizen of an undeveloped, unstable, poor, dictatorial dominated, traditional homeland full of conflict according to many of illegal aliens/sans papiers/ asylum seekers, who travel by plastic boats at the risk of their own lives. Turkey is the main transition points for all of these lifestyle immigrants by land borders (Greece and Bulgaria) and territorial waters (Greek islands). Many immigrants cross Turkey's border to work and save money to deal with smugglers to get on plastic boats to reach at European Union.

From the beginning of Syrian humanitarian crisis, Turkey has open border policy. In addition, Turkey offers up jobs, education and a life opportunity for those asylum seekers via formal amendments for work permits. [4] Also Syrians have been guaranteed with gaining citizenship. [5] Actually 226,109 Syrians and 6,955 Iraqis, totally 233,064 needy immigrants live [6] in terms of shelter, food, cleanliness, health and all other vital opportunities in temporary residence centres (camps) are defined as 'the best camps' ever in worldwide by global media and UNHCR. [7]In 72nd UN General Assembly, Turkey has declared that it has been spent more than $\$ 30$ billion for Syrians during 6 years and there has been no sufficient support to Turkey from advanced countries and global associations. [8] This spending has a hampering effect on Turkey's economy; rise in the supply of labour, unemployment, unfair competition by illegal Syrian enterprises is one dimension next to the positive side of that legal entrepreneurships held by Syrians exceeded 8.000 in Turkey, these businesses cover 100.000 Syrian male workers. [9] In this frame, its own citizens have many socio/cultural and socio-economic problems because of this sudden rise in population in some towns. For instance, local population have faced with insufficiency in public services and house stocks because of accumulation of Syrian population in a very short duration. Also the most uneducated and pauperised Syrian population overwhelmingly children in Turkey are in need of humanitarian reliefs and service procurements. Addition to this, in last holiday for religious eid, 53.798 Syrians have returned to Syria to see their relatives.[10] This situation shows that many Syrians in Turkey are economic immigrants. Another group of Syrians essentially attracts European interests, economic/lifestyle immigrants waiting to go to Europe. Sometimes they have a relative in any European country and they took this conflicts as a chance to immigrate in Europe as a potential 
citizens in future. Many of them have lost their belonging to their homeland and their national identity; they have no idea about returning to Syria; they dream on living allegedly humanist, liberal, wealthy, egalitarian Europe.

\section{Refugee Crisis in European Migration Policies and Xenophobic Rhetoric in Europe}

In the first conflicts and mass movement phase, while Turkey and other developing border countries were struggling with this huge humanitarian problem, advanced European countries were only watching these conflicts, all kind of violence, collapse of a society and humanitarian plights. This silent position of European Union is just like the same as they did during Balkan (Yugoslav/Kosovo) Wars in 1990s and 2000s.History and actuality has many familiarity in that Europe take the humanitarian crisis seriously but only if a refugee crisis threatens borders after the death tolls and traumatic tragedies would mostly done. Syrian humanitarian crisis not only affected border countries, but also European countries especially after the last period of 2014. European countries have been rushing to reform their migration policies and border control mechanisms because of the sharp increase in attends of asylum seekers coming from North African coasts, Turkish land border and territorial waters. Those borderlines are actual transition points for illegal immigrants to arrive at European Union countries (Greece, Italy, Bulgaria and Spain). Since 2015, transition countries and target countries have faced many serious problems to tackle with this human influx in a sudden while. Although they have made border controls and surveillance of illegal immigrants stricter as a reply to Arab Spring [11], this crisis has not been considered as serious by other European countries until Greece and Italy could no more tackle with the increasing numbers of sea arrivals and border crossings proper to Dublin Agreement and Schengen visa agreements..[12] Especially in 2015, there has been a sharp rise in sea arrivals in this routes and Europe have taken this crisis seriously when the first welcoming countries such as Greece and Italy have many difficulties in management of this excessively increasing attends. European Union founder countries noticed the actual refugee crisis by shocking rise of sea arrivals at European coasts. In 2015, Italy and Greece have faced an incredible flow of immigrants and they have no sufficient infrastructure, service and tolerance to tackle with this crisis. Travel of illegal immigrants are easier by human traffickers from hot spots to reach at their target country. As it is on the Table1 below, in 2015 there is no shocking extends and changes in the number of dead/missing immigrants; it is so clear by the data that European countries were shocked due to intensive rise in the number of immigrants who achieved to stay alive and reach at European borders. This means that ramping rate is $469 \%$ as to number of sea arrivals in 2014. Then number of sea arrivals towards Europe, ringed the bells for taking this humanity crisis seriously.

Table 1.Sea Arrivals Dead and Missing in attends to cross Mediterranean sea to Europe

\begin{tabular}{|l|c|c|c|c|}
\hline Mediterranean sea & $\mathbf{2 0 1 7}$ & $\mathbf{2 0 1 6}$ & $\mathbf{2 0 1 5}$ & $\mathbf{2 0 1 4}$ \\
\hline Sea Arrivals & 147,220 & 362,753 & $\mathbf{1 , 0 1 5 , 0 7 8}$ & 216,054 \\
\hline Dead and Missing & 2,785 & 5,096 & 3,771 & 3,538 \\
\hline
\end{tabular}

More than 1 million illegal aliens/sans papiers have arrived to European Union border only in a short time in 2015. This sudden influx of immigrants and the easing the border crossing of illegal immigrants as a strategy of the first welcoming countries to tackle with this crisis can be defined as turning point for a fragment on common EU border and migration policies. Then European countries rationally took the position when their borders begin to be under threat of an extraordinary 
refugee flow. This sudden rise of immigrant population has resulted in strategies for sharing burden by border easements and allowing immigrants to travel which country they want to live on. Because, according to Dublin Agreement, individuals are only able to apply for asylum in a European country where they first entry and enrolled in the system, [13] their applications are only under responsibility of the first country. However this agreement created overwhelming illegal immigrants and most of them coming from conflict areas, famine, natural disasters, mostly from economic difficulties, unemployment and many other pressures have mostly targeting the North Western advanced countries, such as UK, Germany, Belgium, and Holland.

For instance, immigrants illegally crossed the land border of Turkey, travelled under very bad conditions through Bulgaria, Greece, Serbia, Romania, Hungary to Austria and Germany.[14] Immigrants have chosen to enrol and apply for asylum procedures in mostly in Germany and Hungarian president have announced that this "migrant crisis is German problem".[15] Other cases of immigrants from Africa who try to enter in UK, take the route of Ventimiglia (Italy-France border) and Calais (France-UK/tunnel border). This route has been has resulted in tensions and international border crisis among these countries because prevention of illegal crossings. [16] Therefore, they have disputed with the executives in arrival countries such as Greece, Italy, Bulgaria and Spain. The countries where are a deep economic crisis, allow immigrants to cross easily and proceed to northern European countries as to proper for Schengen visa. The first fragment from EU is the Brexit and this obliged European countries to redefine the common agreements and codes.

More than 750.000 Syrians have been entered in Turkey during 6 months in the period of 2015 July2016 January and then the flow has been continued because of that the Syrians who could reach at European countries called their relatives to immigrate by the same route. So, Turkey has openly became the transit point for Syrians trying to take asylum in Europe and especially in October 2015, monthly number of immigrants passing Mediterranean and Aegean Sea totally peaked at 221.638.[17] Especially this great move toward Europe began to make European executives bothered about the security and burden of those refugees. The turning point of the European panic on refugee flow crisis was the shocking effect of a photograph of a Syrian baby boy's dead body lying on the sands in September 2015. [18] After this shocking media image in September 2015, concerns about Syrian refugee flow accelerated the negotiations on the readmission agreement I $E U$ - Turkey deal was signed in March 2016[19].According to the deal, asylum applications for those who pass the EU border are not accepted. Since April 4 2016, illegal immigrants have begun to be sent back to Turkey. After this deal, that is a symbol of opposition to European values strengthened humanism and equality. Non-refoulement procedures, which are the main principle for Universal Human rights and refugee conventions after WW II [20], have been violated by these deal applications. By preventive immigration policies, European countries and EU has stumbled in contradiction between their discourses of human rights and their anti-humanist practices. .For instance according to UNHCR data, as a welfare country proud of universal human rights and humanism, France has accepted only 17,675 Syrians[21] even though it is the G5 countryand since then it has been ranked among the world's countries in terms of development/welfare. However, France is not able to manage only 6.000 illegal immigrants in Calais trying to cross UK by the Eurotunnel.

After EU-Turkey deal, there have been no sea arrivals from Aegean coasts and deal has been successful to stop immigrants dreaming on a sustainable life in Europe. However, these kind of preventive policies have killed the myth of European democratic, humanist and egalitarian values. Northern European countries have been threatened by mass migration in an era of terrorism after 9/11. After Arab movements and chaos in Syria, ISIS and other radical groups have been popularly discoursed by politicians and media to legitimate their xenophobic and also Islamophobic rhetoric in Europe. As to election results, this rhetoric have been supported by European societies more than 
ever before. Generally, European countries have withdrawn many humanist principles of UN conventions and violated many egalitarian human rights by preventive policies, heavy surveillance methods and strict border controls. In addition to this refugee influx, because of the terrorism, societies feel more insecure and this results in anti-immigration, xenophobia, radical nationalism, racism, Islamophobia etc. For instance in European Parliament elections, Marine Le Pen, who has radical xenophobic / Islamophobic rhetoric, had a stunning increase. Her party National Front has won as the first party in European Parliament elections [22], and then she could enter in French parliament in her fifth struggle in the elections. These results show that in the homeland of human rights how society may have a tendency toward xenophobia and anti-immigrant. Other examplesare supports to G. Wilders-PVV in Holland,FPO party in Austria, and AfD party in Germany elections; far right parties which have xenophobic and anti-immigrant rhetoric have been successful more than ever before [23].Also PEGIDA has many aggressive demonstration against Muslims. This kind of policies not only adversely affect on candidates for immigration, but also their own minority citizens and immigrant communities in naturalisation process. Because of that securitisation policies, which are supported by the threats of radical Islamists and terrorists, could easily legitimate antiimmigrant, racist-oriented or Islamophobic rhetoric and attacks in the eyes of public. This tendency results in that innocent people of ethnic or religious minorities increasingly face with discrimination and targeted as scapegoats in society. Securitisation of the socio-politics and depicting the "other" by scapegoating is a dangerous trend surrounding all around the Europe.

\section{References}

1. The World Bank, the Toll of War the Economic And Social Consequences Of The Conflict in Syria, Report, 2017; Saskia Sassen,. "Three Emergent Migrations: An Epochal Change.", SUR 23 - v.13 n.23 • 29 - $41 \mid 2016$.

2. European Commission, "Turkey: Refugee crisis", Facts and Figures, http://ec.europa.eu/echo/files/aid/countries/factsheets/turkey_syrian_crisis_en.pdf

3. Total recorded Syrians in Turkey: 3,222,000. UNHCR, Syria Regional Refugee Response, Inter-agency Information Sharing Portal, 05.10..2017: http://data.unhcr.org/

4. Karar Sayısı:2016/8375, "Geçici Koruma Sağlanan Yanbancıların Çalışma İzinlerine Dair Yönetmelik", Türkiye Cumhuriyeti Resmi gazete, 11/01/2016.

5. Selin Girit, "Turks hit back at Erdogan plan to give Syrians citizenship", BBC News, 5.07. 2016: www.bbc.com/news/world-europe-36704791

6. AFAD, " Barınma Merkezlerindeki Suriyeli Sayısı", Geçici Barınma Merkezleri Raporlart,08.08.2017: https://www.afad.gov.tr

7. Mac Mcclellandfeb. "How to Build a Perfect Refugee Camp", New York Times, 13, 2014; International Crisis Group, Blurring The Borders: Syrian Spillover Risks For Turkey, Report, No: 225, 30.04. 2013, s.8,

8. Türkiye Cumhuriyeti Cumhur Başkanlığı, "We Need to Develop a New Perspective in Order to Promote World Peace", TCCB.gov, 19.09.2017 https://www.tccb.gov.tr/

9. Ali Atar, "8 bini aşkın Suriyeli şirket 100 bin kişiye istihdam sağlıyor", 19.10.2017: aa.com.tr/tr/ekonomi/8-bini-askin-suriyeli-sirket-100-bin-kisiye-istihdam-sagliyor/941924

10. Deniz Çiçek, M. Çalkaya, "Bayramlaşmak için 53 bin 798 Suriyeli”Anadolu Agency, 08.09.2017: aa.com.tr/tr/turkiye/bayramlasmak-icin-53-bin-798-suriyeli-ulkesine-gitti/904275

11. Sergio Carrera, Leonhard Den Hertog, and Joanna Parkin, EU Migration Policy in the wake of the Arab Spring: What prospects for EU-Southern Mediterranean Relations?,MEDPRO Technical Report No. 15/August 2012. 
12. .European Commission, "Schengen, Borders \& Visas": Migration and Home Affairs, https://ec.europa.eu/home-affairs/what-we-do/policies/borders-and-visas_en

13. Bernd Kasparek,"Complementing Schengen: The Dublin system and the European border and migration regime." Migration Policy and Practice. Palgrave Macmillan US, 2016. 5978.

14. UNCHR, "Most common nationalities of Mediterranean sea arrivals".

15. BBC, "Migrant crisis 'a German problem'-Hungary's Orban", 03.09.2015 www.bbc.com/news/world-europe-34136823

16. BBC, "Migrants stranded at Ventimiglia on France-Italy border", 15.06.2015: www.bbc.com/news/world-europe-33131893 ; James Glenday, "Calais Jungle: Tension between UK and France over border asylum seeker camp", 17.09.2016:

17. UNHCR,Operational Portal: http://data2.unhcr.org/en/situations/mediterranean

18. Roland Barthes,"The photographic message.",ed R. T. Craig,. Theorizing Communication: Readings across Traditions, 2000.. T.Wright,. "Moving images: The media representation of refugees", Visual Studies, 17.1 2002: 53-66.

19. Council of the European Union, "EU-Turkey statement", 18/03/2016: www.consilium.europa.eu/en/press/press-releases/2016/03/18-eu-turkey-statement/ ; Al Jazeera, "'Geri kabul' başladı", 4.04.2016 : www.aljazeera.com.tr/haber/geri-kabul-basladi

20. UNHCRNote on Non-Refoulement, EC/SCP/2 , 23.08. 1977:

21. UNHCR, "Europe: Syrian Asylum Applications From Apr 2011 to Jul 2017", : data.unhcr.org/syrianrefugees/asylum.php

22. European Parliament / Results of the 2014 European electionsResults by country 22/09/2014 www.europarl.europa.eu

23. Bowler, Shaun, et al. "Right-wing populist party supporters: Dissatisfied but not direct democrats." European Journal of Political Research 56.1 (2017): 70-91. 